University of Nebraska - Lincoln

DigitalCommons@University of Nebraska - Lincoln

1981

\title{
Limitations in the use of leaf dry weight and leaf number for predicting leaf area of soybeans
}

\author{
S.N. Ogbuehi
}

J.R. Brandle

University of Nebraska - Lincoln

Follow this and additional works at: https://digitalcommons.unl.edu/natrespapers

Part of the Natural Resources and Conservation Commons, Natural Resources Management and Policy Commons, and the Other Environmental Sciences Commons

Ogbuehi, S.N. and Brandle, J.R., "Limitations in the use of leaf dry weight and leaf number for predicting leaf area of soybeans" (1981). Papers in Natural Resources. 1084.

https://digitalcommons.unl.edu/natrespapers/1084

This Article is brought to you for free and open access by the Natural Resources, School of at DigitalCommons@University of Nebraska - Lincoln. It has been accepted for inclusion in Papers in Natural Resources by an authorized administrator of DigitalCommons@University of Nebraska - Lincoln. 


\section{LIMITATIONS IN THE USE OF LEAF DRY WEIGHT AND LEAF NUMBER FOR PREDICTING LEAF AREA OF SOYBEANS'}

\author{
S. N. Ogbuehi and J. R. Brandle ${ }^{2}$
}

\begin{abstract}
Equations relating leaf area to leaf dry weight and to leaf number were developed for soybeans [Glycine max (L.) Merr.] grown in windbreak-sheltered and unsheltered plots during the 1978 and 1979 growing seasons. For each growing season, equations developed for a particular treatment were found to be accurate in predicting leaf area of independent samples taken from that treatment only. In a different treatment or growing season, the equations gave inaccurate estimates. This inaccuracy in predicting leaf area of plants grown in a different treatment or season was attributable to the differences in specific leaf area and leaf size. Our data indicate that prediction equations for soybean leaf area which utilize leaf dry weight and leaf number should not be used for soybeans grown in a different environment because of inaccuracy of estimates.
\end{abstract}

Additional index words: Windbreak-shelter, Prediction equations, Leaf area, Glycine max. (L.) Merr.

$\mathbf{L}^{\mathrm{E}}$ EAF area index is an input into all growth models used in the estimation of canopy light climate, photosynthesis, and evapotranspiration. Its determination is laborious, involving the measurement of leaf area (LA) of large numbers of plants harvested from a known plot area. Consequently, simpler and more rapid methods of LA determination are desirable. Some of the simpler methods now employed utilize the relationship between LA and leaf linear dimensions $(1,4,6,7,11,12$, $13)$, leaf number (11), or leaf or plant dry weight $(3,8,9$, 11). The utility of an equation for predicting LA should be judged by its accuracy to predict LA of independent samples from season to season, and under different cultural and environmental conditions. Rosenberg (10) found an LA prediction formula developed by Davis in 1940 (1) to be accurate in estimating the LA of his irrigated dry beans grown in 1962 and 1963. Sivakumar (11) developed prediction equations for soybean [Glycine max (L.) Merr.] LA using leaf dry weight (LDW) and leaf number (LN) as independent variables. As expected, his equations accurately predicted the actual values used in deriving them. The value of prediction equations comes from the ability of the equations to predict accurately for

\footnotetext{
' Published as Paper No. 5996 Journal Series, Nebraska Agric. Exp. Stn. Received 12 May 1980.

2 Graduate assistant and assistant professor, Dep. of Forestry, Fisheries and Wildlife, Univ. of Nebraska-Lincoln, NE 68583.
}

Table 1. Regreasion equations relating leaf area to leaf dry weight or leaf number for soybeans grown in windbreak. sheltered and unsheltered plots during 1978 and 1979 growing seasons.

\begin{tabular}{|c|c|c|c|c|c|c|c|}
\hline Year & $\begin{array}{c}\text { Environ- } \\
\text { ment }\end{array}$ & & Regression eq & quation & $\begin{array}{l}\text { S.E. of } \\
\text { slope }\end{array}$ & $\mathbf{R}^{\prime}$ & $t$ test \\
\hline \multirow[t]{2}{*}{1978} & $\begin{array}{l}\text { Sheltered } \\
\text { Unsheltered }\end{array}$ & $\begin{array}{l}\mathbf{L A}= \\
\mathbf{L A}=\end{array}$ & $\begin{array}{r}121.6+27 \\
=94.4+239\end{array}$ & $\begin{array}{l}77.0(\mathrm{LDW}) \\
39.1 \text { (LDW) }\end{array}$ & $\begin{array}{l}3.16 \\
3.42\end{array}$ & $\begin{array}{l}0.98 \\
0.96\end{array}$ & $\begin{array}{l}18.63^{*} \\
15.39^{*}\end{array}$ \\
\hline & $\begin{array}{l}\text { Sheltered } \\
\text { Unsheltered }\end{array}$ & $\begin{array}{l}\mathbf{L A}= \\
\mathbf{L A}=\end{array}$ & $\begin{array}{l}=-282.3+ \\
=-364.1+\end{array}$ & $\begin{array}{l}43.9(\mathrm{LN}) \\
37.8(\mathrm{LN})\end{array}$ & $\begin{array}{l}8.32 \\
7.14\end{array}$ & $\begin{array}{l}0.98 \\
0.90\end{array}$ & $\begin{array}{r}8.71^{* \bullet} \\
10.12^{* *}\end{array}$ \\
\hline \multirow[t]{2}{*}{1979} & $\begin{array}{l}\text { Sheltered } \\
\text { Ungheltered }\end{array}$ & $\begin{array}{l}\mathbf{L A}= \\
\mathbf{L A}=\end{array}$ & $\begin{array}{l}81.6+2 \\
61.8+2\end{array}$ & $\begin{array}{l}249.2(\mathrm{LDW}) \\
2 \mathrm{I} 6.3 \text { (LDW) }\end{array}$ & $\begin{array}{l}2.80 \\
6.17\end{array}$ & $\begin{array}{l}0.98 \\
0.98\end{array}$ & $\begin{array}{l}13.42 * \\
17.51\end{array}$ \\
\hline & $\begin{array}{l}\text { Sheltered } \\
\text { Unsheltered }\end{array}$ & $\begin{array}{l}\mathbf{L A}= \\
\mathbf{L A}=\end{array}$ & $\begin{array}{l}=-298.0+ \\
=-326.2+\end{array}$ & $\begin{array}{l}36.1(\mathrm{LN}) \\
25.9(\mathrm{LN})\end{array}$ & $\begin{array}{r}7.16 \\
10.45\end{array}$ & $\begin{array}{l}0.98 \\
0.86 \\
\end{array}$ & $\begin{array}{l}9.67^{\omega *} \\
8.11^{* \circ}\end{array}$ \\
\hline
\end{tabular}

* Significant at the 0.01 probability level.

independent sources of data. We tested the accuracy of Sivakumar's (11) equations in predicting LA of our soybean plants and obtained LA estimates which differed significantly from the control leaf areas measured with an area meter. This observation prompted the study reported here. The objective was to investigate possible environmental and seasonal influences on the relationship between LA and LDW or LN, and thus on the utility of $\mathrm{LA}$ prediction equations utilizing LDW and $\mathrm{LN}$ as independent variables.

\section{MATERIALS AND METHODS}

The study was conducted at the Univ. of Nebraska-Lincoln Field Laboratory, Mead, Nebr., during the 1978 and 1979 growing seasons. The soil was a Typic Argiudoll (Sharpsburg silty clay loam). The treatments consisted of windbreak-shelter and no shelter. Shelter from the wind was provided by a system of shelterbelts established in 1966 for windbreak research. The prevailing wind in Nebraska during the summer months comes from the south. 'Wayne' soybeans were grown at $\$ 26,000$ plants/ha in north-south rows, $92 \mathrm{~cm}$ apart. Sampling to determine LA, LDW and LN was initiated at growth stage V2 (2) and continued at approximately weekly intervals throughout the growth of the crop. Twelve samples were taken during each growing season. During sampling, plants were cut at ground level from six randomly chosen $1 \mathrm{~m}$ lengths of row and taken to the laboratory. Leaf area was determined with an electronic area meter, Model LI-3000, and an accessory transparent belt conveyor, LI-3050 (Lambda Instr. Corp., Lincoln, Nebr.). Trifoliates were counted and dried at $70 \mathrm{C}$ to a constant weight. Prediction equations for LA of plants grown in each of the treatments were computed for each growing season using LDW and LN as independent variables. Eight of the 12 samples collected during the growing season were used to compute each of these equations. The other samples were used to test the ability of the equations to predict LA of independent samples.

\section{RESULTS AND DISCUSSION}

All linear regressions of LA on LDW or LN were highly significant $(P>0.01)$ (Table 1). For each growing season, equations developed for a particular treatment were 
Table 2. Measured and predicted leaf area/plant of independent camples from the 1978 and 1979 sheltered and unsheltered soy. bean plots. Prediction equations used were those derived with loaf dry weight and leaf number data collected from same plots.

\begin{tabular}{|c|c|c|c|c|c|}
\hline \multirow[b]{2}{*}{ Year } & \multirow[b]{2}{*}{ Location } & \multirow{2}{*}{$\begin{array}{l}\text { Days from } \\
\text { planting }\end{array}$} & \multirow{2}{*}{$\begin{array}{l}\text { Measured } \\
\text { leaf area }\end{array}$} & \multicolumn{2}{|c|}{ Prodicted leaf area } \\
\hline & & & & LDW† & $\mathrm{LN} \ddagger$ \\
\hline & & & & $-\mathrm{cm}^{2}-$ & \\
\hline \multirow[t]{2}{*}{1978} & Sheltered & $\begin{array}{l}35 \\
49 \\
62 \\
77\end{array}$ & $\begin{array}{c}442.6 \mathrm{a} \\
1,386.7 \mathrm{a} \\
4,278.2 \mathrm{a} \\
5,346.3 \mathrm{a}\end{array}$ & $\begin{array}{r}431.4 \mathrm{a} \\
1,354.3 \mathrm{a} \\
4,350.0 \mathrm{a} \\
5,398.7 \mathrm{a}\end{array}$ & $\begin{array}{r}429.2 \mathrm{a} \\
1,346.2 \mathrm{a} \\
4,314.4 \mathrm{a} \\
5,367.6 \mathrm{a}\end{array}$ \\
\hline & Unsheltered & $\begin{array}{l}35 \\
49 \\
62 \\
77\end{array}$ & $\begin{array}{r}332.4 \mathrm{a} \\
1,256.5 \mathrm{a} \\
3,464.2 \mathrm{a} \\
4,042.0 \mathrm{a}\end{array}$ & $\begin{array}{r}368.5 \mathrm{a} \\
1,280.1 \mathrm{a} \\
3,500.6 \mathrm{a} \\
3,980.3 \mathrm{a}\end{array}$ & $\begin{array}{r}322.8 \mathrm{a} \\
1,225.5 \mathrm{a} \\
3,514.8 \mathrm{a} \\
4,001.1 \mathrm{a}\end{array}$ \\
\hline 1979 & Sheltered & $\begin{array}{l}39 \\
53 \\
67 \\
82\end{array}$ & $\begin{array}{r}338.6 \mathrm{a} \\
1,180.1 \mathrm{a} \\
3,582.4 \mathrm{a} \\
5,068.2 \mathrm{a}\end{array}$ & $\begin{array}{r}326.4 \mathrm{a} \\
1,201.4 \mathrm{a} \\
3,621.0 \mathrm{a} \\
5,112.6 \mathrm{a}\end{array}$ & $\begin{array}{r}342.5 \mathrm{a} \\
1,224.6 \mathrm{a} \\
3,598.4 \mathrm{a} \\
5,092.2 \mathrm{a}\end{array}$ \\
\hline & Unsheltered & $\begin{array}{l}39 \\
53 \\
67 \\
82\end{array}$ & $\begin{array}{r}280.4 \mathrm{a} \\
1,045.2 \mathrm{a} \\
2,893.3 \mathrm{a} \\
3,780.1 \mathrm{a}\end{array}$ & $\begin{array}{r}298.6 \mathrm{a} \\
991.1 \mathrm{a} \\
2,856.3 \mathrm{a} \\
3,751.1 \mathrm{a}\end{array}$ & $\begin{array}{r}313.1 \mathrm{a} \\
1,010.0 \mathrm{a} \\
2,900.2 \mathrm{a} \\
3,804.4 \mathrm{a}\end{array}$ \\
\hline
\end{tabular}

* Meane in rows followed by the same letter are not significantly different at the 0.01 probability level using Duncan's Multiple Range Test. $\dagger$ Leaf dry weight.

$\ddagger$ Leaf number.

Table 3. Measured and predicted leaf area/plant of the 1978 and 1979 sheltered and unsheltered soybean plots. Prediction equations used for any treatment were those derived with leaf dry weight and leaf number data collected from the other treatment during the same year.

\begin{tabular}{|c|c|c|c|c|c|}
\hline \multirow{2}{*}{$\begin{array}{c}\text { Environ- } \\
\text { ment }\end{array}$} & \multirow[b]{2}{*}{ Year } & \multirow{2}{*}{$\begin{array}{l}\text { Days from } \\
\text { planting }\end{array}$} & \multirow{2}{*}{$\begin{array}{l}\text { Measured } \\
\text { leaf area }\end{array}$} & \multicolumn{2}{|c|}{ Predicted leaf area } \\
\hline & & & & LDW $\dagger$ & LN $\ddagger$ \\
\hline & & & & $-\mathrm{cm}^{2}-$ & \\
\hline \multirow[t]{2}{*}{ Sheltered } & 1978 & $\begin{array}{l}35 \\
49 \\
62 \\
77\end{array}$ & $\begin{array}{c}442.6 \mathrm{a} \\
1,386.7 \mathrm{a} \\
4,278.2 \mathrm{a} \\
5,346.3 \mathrm{a}\end{array}$ & $\begin{array}{r}330.1 \mathrm{~b} \\
1,150.7 \mathrm{~b} \\
3,832.0 \mathrm{~b} \\
4,110.4 \mathrm{~b}\end{array}$ & $\begin{array}{r}298.0 \mathrm{~b} \\
1,094.4 \mathrm{~b} \\
3,796.4 \mathrm{~b} \\
3,094.3 \mathrm{~b}\end{array}$ \\
\hline & 1979 & $\begin{array}{l}39 \\
53 \\
67 \\
82\end{array}$ & $\begin{array}{r}338.6 \mathrm{a} \\
1,180.1 \mathrm{a} \\
3,582.4 \mathrm{a} \\
5,068.1 \mathrm{a}\end{array}$ & $\begin{array}{r}226.8 \mathrm{~b} \\
882.3 \mathrm{~b} \\
3,030.2 \mathrm{~b} \\
4,739.2 \mathrm{~b}\end{array}$ & $\begin{array}{r}215.5 \mathrm{~b} \\
865.7 \mathrm{~b} \\
2,994.0 \mathrm{~b} \\
4,688.6 \mathrm{~b}\end{array}$ \\
\hline \multirow[t]{2}{*}{ Unsheltered } & 1978 & $\begin{array}{l}35 \\
49 \\
62 \\
77\end{array}$ & $\begin{array}{r}332.4 \mathrm{~b} \\
1,256.5 \mathrm{~b} \\
3,464.2 \mathrm{~b} \\
4,042.0 \mathrm{~b}\end{array}$ & $\begin{array}{r}455.6 \mathrm{a} \\
1,612.0 \mathrm{a} \\
4,246.3 \mathrm{a} \\
4,883.6 \mathrm{a}\end{array}$ & $\begin{array}{r}498.3 \mathrm{a} \\
1,654.1 \mathrm{a} \\
4,184.0 \mathrm{a} \\
5,011.1 \mathrm{a}\end{array}$ \\
\hline & 1979 & $\begin{array}{l}35 \\
49 \\
62 \\
77\end{array}$ & $\begin{array}{r}280.4 \mathrm{~b} \\
1,045.2 \mathrm{~b} \\
2,893.3 \mathrm{~b} \\
3,780.1 \mathrm{~b}\end{array}$ & $\begin{array}{r}418.6 \mathrm{a} \\
1,582.4 \mathrm{a} \\
3,736.0 \mathrm{a} \\
4,560.2 \mathrm{a}\end{array}$ & $\begin{array}{r}433.2 \mathrm{a} \\
1,568.5 \mathrm{a} \\
3,692.3 \mathrm{a} \\
4,618.3 \mathrm{a}\end{array}$ \\
\hline
\end{tabular}

* Means in rows followed by the same letter are not significantly different at the 0.01 probability level using Duncan's Multiple Range Test. t Leaf dry weight. $\ddagger$ Leaf number.

found to be accurate in predicting LA of independent samples taken from that treatment (Table 2), but inaccurate in predicting LA of plants grown in a different treatment (Table 3). Equations developed for a particular growing season were also inaccurate in predicting LA of plants grown in another growing season (Tables 4 and 5).

The equations developed for unsheltered conditions always underestimated LA of sheltered plots, and vice versa. Similarly, equations developed for a treatment in 1979 underestimated LA of plants grown in that treatment in 1978, and vice versa. These inaccuracies in predicting LA of plants grown in a different treatment or
Table 4. Measured and predicted leaf area/plant of 1979 sheltered and unsheltered soybean plots. Prediction equations used were those derived with leaf dry weight and leaf number data collected from the same treatment in 1978.

\begin{tabular}{|c|c|c|c|c|}
\hline \multirow[b]{2}{*}{ Location } & \multirow{2}{*}{$\begin{array}{l}\text { Days from } \\
\text { planting }\end{array}$} & \multirow{2}{*}{$\begin{array}{l}\text { Measured } \\
\text { leaf area }\end{array}$} & \multicolumn{2}{|c|}{ Predicted leaf area } \\
\hline & & & LDW $†$ & LN $\ddagger$ \\
\hline Sheltered & $\begin{array}{l}39 \\
53 \\
67 \\
82\end{array}$ & $\begin{array}{c}338.6 \mathrm{~b} * \\
1,180.1 \mathrm{~b} \\
3,582.4 \mathrm{~b} \\
5,068.1 \mathrm{c}\end{array}$ & $\begin{array}{r}522.0 \mathrm{a} \\
1,845.3 \mathrm{a} \\
4,280.2 \mathrm{a} \\
5,740.1 \mathrm{~b}\end{array}$ & $\begin{array}{r}498.4 \mathrm{a} \\
1,788.1 \mathrm{a} \\
4,322.4 \mathrm{a} \\
5,860.7 \mathrm{a}\end{array}$ \\
\hline Unsheltered & $\begin{array}{l}39 \\
53 \\
67 \\
82\end{array}$ & $\begin{array}{r}280.4 \mathrm{~b} \\
1,045.2 \mathrm{~b} \\
2,893.3 \mathrm{~b} \\
3,780.1 \mathrm{~b}\end{array}$ & $\begin{array}{r}454.2 \mathrm{a} \\
1,487.3 \mathrm{a} \\
4,011.9 \mathrm{a} \\
5,621.0 \mathrm{a}\end{array}$ & $\begin{array}{r}486.1 \mathrm{a} \\
1,472.6 \mathrm{a} \\
4,063 . \mathrm{a} \\
5,590.0 \mathrm{a}\end{array}$ \\
\hline
\end{tabular}

* Means in rows followed by the same letter are not significantly different at the 0.01 probability level using Duncan's Multiple Range Test. † Leaf dry weight. $\quad \ddagger$ Leaf number.

Table 5. Measured and predicted leaf area/plant of 1978 sheltered and unsheltered soybean plots. Prediction equations used were those derived with leaf dry weight and leaf number data collected from the same treatment in 1979.

\begin{tabular}{|c|c|c|c|c|}
\hline \multirow[b]{2}{*}{ Location } & \multirow{2}{*}{$\begin{array}{l}\text { Days from } \\
\text { planting }\end{array}$} & \multirow{2}{*}{$\begin{array}{l}\text { Measured } \\
\text { leaf area }\end{array}$} & \multicolumn{2}{|c|}{ Predicted leaf area } \\
\hline & & & LDW† & LN $\ddagger$ \\
\hline & & & $\mathrm{cm}^{2}$ & \\
\hline Sheltered & $\begin{array}{l}35 \\
49 \\
62 \\
77\end{array}$ & $\begin{array}{l}442.6 \mathrm{a}= \\
1,386.7 \mathrm{a} \\
4,278.2 \mathrm{a} \\
5,346.3 \mathrm{a}\end{array}$ & $\begin{array}{r}254.1 \mathrm{~b} \\
1,046.9 \mathrm{~b} \\
3,467.8 \mathrm{~b} \\
3,887.0 \mathrm{~b}\end{array}$ & $\begin{array}{r}242.8 \mathrm{~b} \\
1,100.0 \mathrm{~b} \\
3,511.1 \mathrm{~b} \\
3,910.4 \mathrm{~b}\end{array}$ \\
\hline Unsheltered & $\begin{array}{l}35 \\
49 \\
62 \\
77\end{array}$ & $\begin{array}{r}332.4 \mathrm{a} \\
1,256.5 \mathrm{a} \\
3,464.2 \mathrm{a} \\
4,042.0 \mathrm{a}\end{array}$ & $\begin{array}{r}200.1 \mathrm{~b} \\
987.3 \mathrm{~b} \\
2,840.5 \mathrm{~b} \\
3,121.0 \mathrm{~b}\end{array}$ & $\begin{array}{r}186.6 \mathrm{~b} \\
933.4 \mathrm{~b} \\
2,783.1 \mathrm{~b} \\
3,084.4 \mathrm{~b}\end{array}$ \\
\hline
\end{tabular}

* Means in rows followed by the same letter are not significantly differ ent at the 0.01 probability level using Duncan's Multiple Range Test.

† Leaf dry weight. $\ddagger$ Leaf number.

Table 6. Average specific leaf area and leaf size during 1978 and 1979 growing geasons in windbreak-sheltered and unshelterod plante.

\begin{tabular}{|c|c|c|c|c|}
\hline \multirow[b]{2}{*}{ Year } & \multicolumn{2}{|c|}{ Avg. SLAT } & \multicolumn{2}{|c|}{ Avg. leaf size } \\
\hline & Sheltered & Unsheltered & Sheltered & Unsheltered \\
\hline & - & $\mathbf{g}$ & 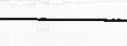 & - \\
\hline $\begin{array}{l}1978 \\
1979\end{array}$ & $\begin{array}{l}326.8 \mathrm{a}= \\
293.2 \mathrm{~b}\end{array}$ & $\begin{array}{l}294.2 \text { b } \\
280.4 \text { c }\end{array}$ & $\begin{array}{l}114.7 \mathrm{a} \\
105.9 \mathrm{c}\end{array}$ & $\begin{array}{l}110.4 \mathrm{~b} \\
101.0 \mathrm{~d}\end{array}$ \\
\hline
\end{tabular}

* Means under SLA or leaf size followed by the same letter are not significantly different at the 0.01 probability level using Duncan's Multiple Range Test. † Specific leaf area.

season were attributable to the differences between treatments and between seasons in specific leaf area and leaf size (Table 6).

Our data indicate that prediction equations for soybean LA that use LDW or LN give very inaccurate estimates of LA of plants grown in a different environment or season.

\section{REFERENCES}

1. Davis, J. F. 1940. The relationship between leaf area and yield of the field bean with a statistical study of methods for determining leaf area. Agron. J. 32:323-329.

2. Fehr, W. R., C. E. Caviness, D. T. Burmood, and J. S. Pennington. 1971. Stage of development descriptions for soybeans [Glycine max (L.) Merrill]. Crop Sci. 11:929-991. 
3. Johnson, R. E. 1967. Comparison of methods for estimating cotton leaf area. Agron. J. 59:493-494.

4. Kemp, C. D. 1960. Methods of estimating the area of grasses from linear measurements. Ann. Bot. (London) 24:491-499.

5. Koller, H. R. 1972. Leaf area-leaf weight relationships in the soybean canopy. Crop Sci. 12:180-183.

6. Pearce, R. B., J. J. Mock, and T. B. Bailey. 1975. Rapid method for estimating leaf area per plant in maize. Crop Sci. 15:691-694.

7. Reynolds, S. G. 1971. A forestry note on the estimation of leaf area of cocoa (Theobroma cacao L.) from three leaf parameters. Trop. Agric. 48:177-179.

8. Rhoads, F. M., and M. E. Bloodworth. 1964. Area measurement of cotton leaves by a dry-weight method. Agron. J. 56:520-522.

9. Robinson, C. D., and M. A. Massengale. 1967. Use of area-weight relationship to estimate crop area in alfalfa (Medicago sativa $\mathbf{L}$. cultivar 'Moapa'). Crop Sci: 7:394-395.

10. Rosenberg. N. J. 1966. Microclimate, air mixing. and physiological regulation of transpiration as influenced by wind shelter in an irrigated bean field. Agric. Meteorol. 3:197 224.

11. Sivakumar, M. V. K. 1978. Prediction of leaf area index in soybean [Glycine max (L.) Merrill]. Ann. Bot. (London) 42:251-253.

12. Wendt, C. W. 1967. Use of a relationship between leaf lengths and leaf area to estimate the leaf area of cotton (Gossypium hirsulum L.), castors (Ricinus communis L.), and sorghum (Sorghum vulgare L.). Agron. J. 59:484-486.

13. Wiersma, J. V., and T. B. Bailey, 1975. Estimation of leaflet, trifoliolate, and total leaf areas of soybeans. Agron. J. 67:26-30. 